\title{
Factors Influencing Customer Loyalty Toward Online Shopping
}

\author{
Sri Astuti Pratminingsih, Christina Lipuringtyas, and Tetty Rimenta
}

\begin{abstract}
The significant growth of online shopping makes the competition in this industry become more intense. Maintaining customer loyalty has been recognized as one of the essential factor for business survival and growth. The purpose of this study is to examine empirically the influence of satisfaction, trust and commitment on customer loyalty in online shopping. This paper describes a theoretical model for investigating the influence of satisfaction, trust and commitment on customer loyalty toward online shopping. Based on the theoretical model, hypotheses were formulated. The primary data were collected from the respondents which consists of 300 students. Multiple regression and qualitative analysis were used to test the study hypotheses. The empirical study results revealed that satisfaction, trust and commitment have significant impact on student loyalty toward online shopping.
\end{abstract}

Index Terms-Online shopping, satisfaction, trust, commitment, loyalty.

\section{INTRODUCTION}

Internet is a relatively new communication media in Indonesia, an archipelago that spans over more than 17,001 islands. Based on Communication Ministry data, in 2011, there are 55 million internet users in Indonesia, which 80 percent users on the age of 15 to 30 years old [1]. Many business have developed their marketing strategies by combining the offline (conventional stores) to online store in order to take this opportunity. The value of online shopping transaction in Indonesia in 2012 reached around USD 266 million or IDR 2.5 trillion. The number is predicted to go up $79.7 \%$ to USD 478 million (around IDR 4.5 trillion) in 2013. In 2014, the value of Indonesian online transaction is predicted to reach USD736 million (around IDR7.2 trillion). Indonesian people's tendency to shop online will increase $14 \%$ in the next 6 months [2] and $68 \%$ of Indonesia's online population had shopped online at least once [3].

There are various benefits of online shopping which encourage people to participate in online transaction. Those benefits are: the global reach of the internet, whereby consumers can buy goods and services with a wide range of categories anywhere, any time and at any location. Besides, online sellers deliver the goods to the buyer's home, and customers can order as many items as they can afford [4],

Manuscript received April 25, 2013; revised June 20, 2013

Sri Astuti Pratminingsih is with The Widyatama University, Bandung, Indonesia. (e-mail : sri.astuti@widyatama.ac.id)

Christina Lipuringtyas and Tetty Rimenta Lipuringtyas are with State Poly technique of Jakarta, Kampus UI Depok, Indonesia (e-mail : lipur27@gmail.com,rimenta@yahoo.com)
[5]. Despites its advantages of using online shopping, consumers still reluctant to purchase from websites because of various factors such as the legitimacy of the a websites, product quality, security and information privacy and also post purchase service and trust [4] - [6]. Trust is seen to be one of the critical factors in online shopping because lack of direct contact and consumers have to hand in personal information to complete the transaction, therefore purchasing online is considered risky [7], [8]. Lack of trust may cause consumers to avoid the e- vendors[9].

Various researchers have examined many different factors involving the construct of loyalty such as satisfaction, trust and commitment [10]-[14] in e commerce. Nevertheless, empirical research on e commerce customer satisfaction, trust and commitment in Indonesia is still limited. The objectives of this study is to examine the key antecedents that influence online shopping satisfaction, trust, commitment and loyalty in Indonesia. This paper is organized as follows. First the study offers a discussion of the nature of loyalty, satisfaction, trust and commitment. Second, the paper developed several hypotheses about the influence of satisfaction on trust and commitment in turn influence loyalty. This is followed by methodology used in this paper to examine the model. Finally, the study discussed the results and provides potential implications for further research.

\section{LITERATURE REVIEW}

\section{A. Customer Loyalty}

Customer loyalty plays a critical role in an organization's success and customer loyalty becomes more important especially when customer acquisition alone does not equate to long term success [15]. Customer loyalty is the main objective for strategic marketing planning since it brings about many favorable outcomes to companies. First, it is much less expensive to retain current customer than it is to seek new ones [16]. Further, loyal customers are more likely to discuss past service experiences positively than non-loyal customers, creating a potential for word-of-mouth advertising at no extra cost to the service provider [17]. Third, it secures the relationship between customer and service provider. Finally, loyal customers are more easily accessible than first-timers since organizations usually retain records, making targeted indirect marketing more feasible. This knowledge permits suppliers to precisely target the repeat segment and solicit direct responses to promotions [18].

Customer loyalty occurs when a custommer buy a product or service repeatedly, and he/she holds appropriate 
and positive attitude towards goods and services of the companies[19]. Oliver [20] has proposed four ascending brand-loyalty stages according to the cognition-affectconation pattern. The first stage is cognitive loyalty. Customers are loyal to a brand based on their information on that brand. The next phase is affective loyalty, which refers to customer liking or positive attitudes toward a brand. The third step is conative loyalty or behavioral intention. This is a deeply held commitment to buy a "good intention." This desire may result in unrealized action. The last stage is action loyalty, where customers convert intentions into actions. Customers at this stage experience action inertia, coupled with a desire to overcome obstacles to make a purchase. Although action loyalty is ideal, it is difficult to observe an is often equally difficult to measure. As a compromise, most researchers tend to employ the conative or behavioral-intention measure.

In online shopping, e- loyalty is defined as a customer's favorable attitude and commitment towards the online retailer that result in repeat purchase behavior [21]. Eloyalty expresses customer favorable attitude toward an ecommerce website that predisposes the customer to repeat buying behavior [22]. Loyal customer always have intention to buy from website and not switch to another web site [23]. Tam [24] also stated that loyal customers always spread favorable messages about their service provider and recommend new customers to the company. The core of loyalty is the customer's ability to turn out competitors efforts to persuade consumer into switching product or services and recommend e- service provider to others.

Loyalty can be examined through behavioral and attitudinal loyalty. Behavioral loyalty is customer willingness to continue a relationship and repurchase the product. Attitudinal loyalty is the level of the customer's attitudinal advocacy and psychological attachments to the service provider [25] - [26]. Another way to measure loyalty is using composite approach. This approach argued that customer loyalty is regarded as an integration of behavioral measures (in the sense of exclusive purchase, hard-core loyalty, repeat purchase probability, share of category requirements, etc.) and attitude (with reference to brand preference, liking, commitment, intention-to-buy. [27].

\section{B. Customer Satisfaction}

The key for retaining the customer is customer satisfaction. Customer satisfaction can be defined as a consumer's feeling of pleasure or disappoinment resulting from comparing a product's perceived performance (or outcome) in relation to his/her expectation [16].

Anderson and Srinivasan [21], defined satisfaction as the contentment of the customer with the respect to his/her prior purchasing experience with a given service firm. Satisfaction in online marketing is customer judgment of their internet experience as compared to their experience with traditional offline service provider or retail stores [28]. As customer satisfaction reflects the degree of a customer's positive feeling about a service provider, it is important for service providers to understand customers' perception of their services.

Customer satisfaction is an important antecedents for customer loyalty [16]. This relationship would seem to be applicable to Internet e-commerce [29].Satisfied customers tend to have higher usage of services, and posess stronger repurchase intention [16]. Customers' satisfaction with a certain e-service provider are expected to increase their willingness to make more online purchasing from that service provider [30] . Rust and Zahorik [31] stated that greater customer satisfaction leads to greater intent to repurchase. According to Anderson and Sullivian [21], a high level of customer satisfaction will decrease the perceived need to switch service provider, thereby increasing customer repurchase and ultimately enhancing profitability of the organization [32].

Henig and Klee [33] further argued that satisfaction will positively influence commitment. A high level of satisfaction provides the customer with repeated positive reinforcement that will create commitment and loyalty.

\section{C. $\quad$ Trust}

Trust is a critical success factor in successful service relationships because before conduct business with the company consumers need to trust the company [34]. The marketing literature supports a positive relationship between trust and satisfaction [35] since the presence of trust raises levels of performance and causes greater satisfaction [36]-[37].

Especially online, it was pointed out that the lack of online consumer trust was the main barrier of consumer participation in e-commerce [38] and has been found to be one of the major obstacles to the popularity of internet transaction [39].

E-trust is the degree of confidence customers have in online exchanges, or in the online exchange channel [40][9]. Online trust includes consumer perception of how the website would deliver on expectation, how believable the website's information is, and the level of confidence in site channel [41].Trust appears to be especially important for creating loyalty in online service as it is perceived as high level risk transaction since customers lack direct contact with the company and have to hand over sensitive personal information, such as credit card numbers, in order to complete the transaction [21]- [42].

Kim et al. [43] identified ability, benevolence and integrity as three principal components of trust. It is suggested that trust will contribute to both commitment and loyalty. There are also some evidences supporting a positive relationship between e-tailer trust and e- loyalty, in term of increased spending [44], and intentions to purchase [45] or repurchase. E- trust also have positive and significant influence on e-commitment [46].

\section{Commitment}

Commitment express the desire for continuity manifest by the willingness to invest resources in a relationship [45]. Morgan and Hunt [47] defined relationship commitment as the belief between transaction partners that maintaining their continuous relationship is important and are willing to exert their best effort to maintain it. Relationships are built on the foundation of mutual commitment and to benefit both parties in the long run. Several researchers [14], [11], [48] stated that commitment, the most important attitudinal measure, is a significant 
indicator of loyalty, as it represents an emotional or psychological attachment to a brand within a product class. In addition, a degree of dispositional commitment in terms of some unique values associated with the brand is part of attitudinal brand loyalty [25].

The customer and service provider commitment are crucial in business relationship, without which the relationship will not sustain, and finally relationship should contribute to the satisfaction of involved parties[11]. Wu et al [49] stated that commitment as a customer's longterm ongoing orientation toward a relationship grounded on both emotional bond to the relationship (affective aspect) and on the conviction that remaining in the relationship will yield net benefits than terminating it (cognitive aspect). Commitment are regarded as antecedents of repeat purchase behavior [50]. E-commitment shown to have significant impact on e-loyalty [51].

\section{HYPOTHESIS}

Based on the literature review, the hypothesis of tis study are:

H1: E - satisfaction directly influences trust of online shopping

$\mathrm{H} 2$ : E-satisfaction directly influences e- loyalty

H3: E-satisfaction directly influences e-commiment

H4: E-trust directly influences e- loyalty

H5: E- trust directly influences commitment

H6: E-commitment directly influences e- loyalty

\section{RESEARCH METHOD}

\section{A. Research Objective}

The objective of this study is to examine the influence of customer satisfaction, trust as primary factor for customer commitment and loyalty.

\section{B. Sample}

In Indonesia, $73 \%$ of the internet users are of age between 15-34 years old [3]. Therefore the target respondents for this research would be university students. Most of college students access the internet daily. The samples were selected from university students in Bandung, Indonesia, consists of 300 students. The selection of the respondents were using convenience sampling.

\section{Instrument}

Scale items for assessing key constructs, such as customer satisfaction, trust, commitment and loyalty, were adapted from prior studies' validated measures. The respondents were requested to indicate the extent to which they agree or disagree, based on their experiences, by checking the appropriate response to the questionnaire items regarding the key constructs of the study. The questionnaire is divided into 2 sections: The first section of the questionnaire is demographic information which includes such questions as: gender, age, education, etc. The second section contained 19 items aimed at measuring constructs for satisfaction, trust, commitment, and loyalty, as recommended in the literature. Each construct were rated on a 5-point Likert scale, ranging from 1 (strongly disagree) to 5 (strongly agree). Items were randomly ordered. Satisfaction measured using the instrument developed by Fullerton [51] consists of 4 items. Trust was measured using instrument developed by Gefen et.al, [9]. Commitment measured using the scales developed by [50]. Scales taken from Zeithaml et.al [52] measured advocacy loyalty and repurchase loyalty, which consist of 6 items.

\section{Data Collection}

The data used in this research has been collected from a private university in Bandung, Indonesia. Questionnaire was distributed to 300 students who have access to internet and have the experience of purchasing online stores. All respondents were voluntarily recruited.

The respondents are asked to evaluate the designed items within the questionnaire. There are 300 respondents filling out the questionnaire. Among the 300 questionnaires retrieved, 35 questionnaires are invalid, 265 were usable ( $88 \%$ response rate).

\section{FINDING AND DISCUSSION}

\section{A. Respondent Profile}

\section{1) Gender}

Based on 265 sample student of a private university, the percentage of male and female respondents are 59 percent and 41 percent respectively, which shows that the male dominancy of online customers.

TABLE I : GENDER

\begin{tabular}{|c|c|c|}
\hline Gender & Frequency & $\%$ \\
\hline Male & & 59 \\
\hline Female & & 41 \\
\hline Total & 265 & 100 \\
\hline
\end{tabular}

2) Age

Based on the age of respondents, 61 percent are at the range of 17 to 20 years old, 31 percent are at the range of 21 to 24 years old, and 8 percent are more than 24 years old.

TABLE II : AGE

\begin{tabular}{lcc}
\hline \multicolumn{1}{c}{ Age } & Frequency & $\%$ \\
\hline $17-20$ & & 61 \\
$21-24$ & 31 \\
$>24$ & 8 \\
Total & 100 \\
\hline \hline
\end{tabular}

\section{3) On-line shopping experience}

The study revealed that most of respondent have one to three years experience in on-line shopping. This condition is understandable because e commerce in Indonesia is a new marketing media compared to conventional marketing.

TABLE III: ON-LINE SHOPPING EXPERIENCE

\begin{tabular}{lcc}
\hline \multicolumn{1}{c}{ Length } & Frequency & $\%$ \\
\hline$<1$ year & & 44 \\
$1-2$ & 38 \\
$3-4$ & 13 \\
$>4$ & 5 \\
Total & 100 \\
\hline \hline
\end{tabular}


In the whole sample, 61 percent are at the range of 17 to 20 years old, 31 percent are at the range of 21 to 24 years old, and 8 percent are more than 24 years old. In term of their experience in online shopping, 13\% are having 2 to 3 years experience of online shopping, 38 percent have 1 to 2 years experience of online shopping and 44 percent have less than one year experience of online shopping. In term of their frequency online purchase, 6 percent have 6 to 10 transactions in the last six month, 19 percent have 4 to 5 transactions in the last six month, 42 percent have 2 to 3 transactions in the last six month, 31 percent only have one transactions and 2 percent has more than 10 transactions in the last six months.

\section{4) Validity and Reliability}

\section{a) Validity of the scale}

In this study, the validity of the construct was measured by checking the square root of the average variance for each construct. Table I, showed that the value of all constructs are above 0.3 , those value indicated that the constructs are valid as suggested by Sugiono [51].

TABLE IV : VALIDITY OF CONSTUCTS

\begin{tabular}{|c|c|c|c|c|c|c|}
\hline & & $\begin{array}{c}\text { Satisfac } \\
\text { tion }\end{array}$ & Trust & $\begin{array}{c}\text { Commit } \\
\text { ment }\end{array}$ & $\begin{array}{l}\text { Loyal } \\
\text { ty }\end{array}$ & Total \\
\hline \multirow[t]{3}{*}{ Satisfaction } & Pearson Correlation & 1 & $.661^{* *}$ & $.541^{* *}$ & $.697^{* *}$ & $.854^{* *}$ \\
\hline & Sig. (2-tailed) & & .000 & .000 & .000 & .000 \\
\hline & $\mathrm{N}$ & 264 & 264 & 264 & 264 & 264 \\
\hline \multirow[t]{3}{*}{ Trust } & Pearson Correlation & $.661^{* *}$ & 1 & $.566^{* *}$ & $.605^{* *}$ & $.805^{* *}$ \\
\hline & Sig. (2-tailed) & .000 & & .000 & .000 & .000 \\
\hline & $\mathrm{N}$ & 264 & 264 & 264 & 264 & 264 \\
\hline \multirow[t]{3}{*}{ Commitment } & Pearson Correlation & $.541^{* *}$ & $.566^{* *}$ & 1 & $.537^{* *}$ & $.784^{* *}$ \\
\hline & Sig. (2-tailed) & .000 & .000 & & .000 & .000 \\
\hline & $\mathrm{N}$ & 264 & 264 & 264 & 264 & 264 \\
\hline \multirow[t]{3}{*}{ Loyalty } & Pearson Correlation & $.697^{* *}$ & $.605^{* *}$ & $.537^{* *}$ & 1 & $.890^{* *}$ \\
\hline & Sig. (2-tailed) & .000 & .000 & .000 & & .000 \\
\hline & $\mathrm{N}$ & 264 & 264 & 264 & 264 & 264 \\
\hline \multirow[t]{3}{*}{ total } & Pearson Correlation & $.854^{* *}$ & $.805^{* *}$ & $.784^{* *}$ & $.890^{* * *}$ & 1 \\
\hline & Sig. (2-tailed) & .000 & .000 & .000 & .000 & \\
\hline & $\mathrm{N}$ & 264 & 264 & 264 & 264 & 264 \\
\hline
\end{tabular}

\section{b) Reliability}

Cronbach coefficient alpha is the most common accepted formula for assessing the reliability of measurement scale with multi point item [54]. The realibility of the construct is considered acceptable, as Cronbach's alpha and composite reliability coeficients offer values which, in all cases are appreciably higher than the recommended value of 0.7 [54]. The reliability of each construct is: Loyalty 0,835 ; Satisfaction 0,748; Trust 0,700 and commitment 0,825 . Therefore, all constructs are valid.

TABLE V : RELIABILITY OF CONSTRUCT

\begin{tabular}{lc}
\hline \multicolumn{1}{c}{ Description } & Cronbach Alpha Value \\
\hline Loyalty & 0.835 \\
Satisfaction & 0.743 \\
Trust & 0.700 \\
Commitment & 0.825 \\
\hline \hline
\end{tabular}

B. The Correlation of Customer Satisfaction, Trust, Commitment and Customer Loyalty

A multiple regression analysis was performed to examine the relationship among customer satisfaction, trust, commitment and customer loyalty.

\section{1) The correlation of satisfaction and trust}

Fig. 1 illustrates the study results. The study results shows that satisfaction has positive and strong relationship with trust $(\beta=0.667, \mathrm{p}<0.05)$ which appears to correspond to Syah alam [4] and Lee et al.'s [43] suggestion that customers satisfaction with the website strongly influence their trust in the online services. Positive experiences with the current online services have been satisfactory and customer feel they have made a correct decision when choosing their service provider. This has led the customer to continuously choose the same website for successive visits. R2 for the model is $0.474,47.4 \%$ of variation in customer satisfaction explained customer trust.

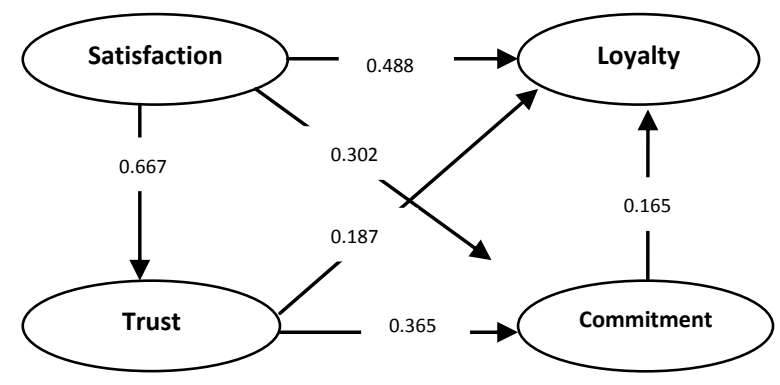

Fig. 1. The correlation of customer satisfaction, trust, commitment and customer loyalty

\section{2) The correlation of trust and loyalty}

The study also reveals that trust influence loyalty significantly $(\beta=0.187, \rho<0.05)$. Therefore, the result supports the hyphothese. This finding also supported by previous researh Gomez, [55] who found that customer trust will effect customer loyalty to a service provider or stores. Valenzuela [56] also argued that satisfied and trusting customers will become committed to the company and committed customers will become loyal customers. that trust contribute to building customer satisfaction.

\section{3) The correlation of trust and commitment}

The influence of trust on commitment receives support $(\beta=0.365, p<0.05)$. That is, customer's trust in the online service flourishes and is favorable due to the fact that the online service provider is perceived as committed, sincere, honest and transparent when offering its services customers believe it would not intentionally attempt anything that would jeopardize the customers. The results also reveal that $\mathrm{R} 2=0.133,13.3 \%$ of variation in customer trust explained customer commitment. This indicated that as trust increases, commitment tends to get stronger. This finding supports the survey of Garbarino and Johnson [11] that commitment is achieved through trust establishment.

\section{4) The Correlation of satisfaction and commitment}

The relationship between customer satisfaction and commitment is supported $(\beta=0.302, \mathrm{p}<0.05)$ which appears to correspond to Mahajar and Yunus [57] suggestion that customers satisfaction with the website positively influence their commitment in services provider. If customer satisfied and customer feel they have made a correct decision when choosing their service provider, they 
will committed to the service provider. $\mathrm{R} 2$ for the model is $0.091 \%$ of variation in customer satisfaction explained customer commitment.

\section{5) The relationship of commitment and loyalty}

The regression result shows that customer commitment directly and positively affects on line loyalty $(\beta=0.165$, $p$ $<0.05$ ). Therefore, result infers that $\mathrm{R} 2=0.289,28.9 \%$ of the variation in customer commitment explained customer loyalty. Loyalty develops as customer visit the website more often than other website and become committed to the website. Even if they are presented with new alternatives, they intend to maintain their relationship with this particular website. If somebody criticizes the current website, they would rather emphasize the website positive feature. The result is consistent with the empirical research findings by Kim[45].

\section{6) The relationship of satisfaction and loyalty}

The study exhibited that influential levels of customer satisfaction factor on customer loyalty was statistically significant $(\beta=0.667, \rho<0.05)$ and 48.8 percent of overall customer loyalty was explained by the factor of customer satisfaction. This finding is in agreement with the findings of previous researches which proved that the higher level of customer satisfaction will lead to greater customer loyalty [15], [16].

TABLE VI : HYPOTHESES OF THE STUDY

\begin{tabular}{clccc}
\hline \hline No & \multicolumn{1}{c}{ Hypotheses } & Beta & Sig & Results \\
\hline 1 & H1: Satisfaction influence & .667 & .000 & $\begin{array}{c}\text { Strongly } \\
\text { supported }\end{array}$ \\
2 & $\begin{array}{l}\text { trust significantly. } \\
\text { H2: Satisfaction influence } \\
\text { commitment significantly. }\end{array}$ & .302 & .000 & Supported \\
3 & $\begin{array}{l}\text { H3: Trust influence } \\
\text { commitment significantly. }\end{array}$ & .365 & .000 & Supported \\
4 & $\begin{array}{l}\text { H4: Satisfaction influence } \\
\text { loyalty significantly. }\end{array}$ & .488 & .000 & Supported \\
5 & $\begin{array}{l}\text { H5: Trust influence loyalty } \\
\text { significantly. }\end{array}$ & .187 & .002 & Supported \\
6 & $\begin{array}{l}\text { H6: Commitment influence } \\
\text { loyalty significantly. }\end{array}$ & .165 & .002 & Supported \\
\hline \hline
\end{tabular}

\section{Discussion}

This research intended to investigate the factors that influence customer loyalty in online service. The objective of the study was to provide a comprehensive conceptual model of customer loyalty and its antecedents for this service sector and for those who share common characteristics.

The key findings of the study include the acceptance of proposed model and hypotheses. First outcome of the results is satisfaction is positively associated with eloyalty. Results show significant positive relation. It has been confirmed that customer satisfaction is one of the major antecedents of e- loyalty [22].

Satisfaction and trust are conceptually connected. The results signal strong positive significant relationships validated through another study results of Delgado et al. [58]. The study also revealed that though satisfaction- commitment relationship is not so strong, but still, increase in satisfaction level enhances the commitment and trust of customers. Commitment to a preferred online service develops loyalty for that service provider. Lee et al. [43], provided the evidence that increased commitment level enhances customer loyalty.The results show that trust and customer loyalty are conceptually connected and have positive significant relationship.

Based on the findings, satisfaction, trust and commitment are very important variables for online shopping. On line shopping managers should take into account that both customer satisfaction and trust are required because both will influence commitment and loyalty. Previous research [13], [19], [23] has pointed out that ease of use, information content, innovation, security protection, customer service, transaction and delivery process are factors that will influence on-line satisfaction. Thus, creating and maintaining satisfaction through its antecedents is an appropriate and necessary strategy for establishing customer satisfaction.

Studies on customer on-line experience [13], [14] have shown that good experience on on-line shopping has positive and significant influence on trust and loyalty. Therefore, Managers of on-line stores also have to pay attention to customer on-line experience, from first encounter, purchase, delivery through after sales service because online experience may influence consumers satisfaction with the e service which in turn will also influence customer trust, commitment and loyalty.

\section{CONCLUSION}

According to the results of the study, all six hypotheses are supported. Satisfaction has positive relationship with trust,commitment, and loyalty. Trust also has positive relationship with commitment and loyalty, and commitment has impact on loyalty.

The results of the study indicated that customer satisfaction showed great impact on customer loyalty. The existence of e-loyalty emerged from experience. The experience that was gained during the first transaction increases the possibility of purchasing in the same online store again. Therefore, we recommend that shop owner needs to focus on the online shopping experience. In addition, gaining consumer trust is very important in online shopping. Customers may tend to stay on the online shopping malls if they trust the service provider because online transaction does not allow customers to see the goods before they purchase. Additionally, this can be implemented by offering good service quality, incentives and promotions to customers.

\section{REFERENCES}

[1] Jakarta Post, Iinternet users in Indonesia reaches 55 million people, $28^{\text {th }}$ October 2011

[2] A. Miftachul, Indonesia e-commerce transaction in 2012 woth IDR 2.5 Trillion, en. dailysocial/net. 2012.

[3] A Broader look at Indonesia Start-up and Internet business prospects. [Online]. Available: http://coolfounders. com/

[4] S. Alam and N. M. Yasin, "What factors influence online brand trust: evidence from online tickets buyers in Malaysia," Journal of Theoretical and Applied Electronic Commerce Research, vol. 5, issue 3, pp. 78-89, December 2010. 
[5] D. Buchalis, "E- airlines: Strategic and tactical use of ICTs in the airline industry," Information and management, vol. 41, pp. 805825, 2004.

[6] C. Y. Chen, "The effect of online store images and risk perception on internet purchase intention," Fu Jen Chatholic University, 2006.

[7] F. F. Reichheld and P. Schefter, "E - Loyalty: Your secret weapon on the web," Havard Business Review, vol. 78, no. 4, pp. 105-113, 2000.

[8] F. Ciptono and G. Chandra, Service Quality and satisfaction, Andi Offset Publisher, Yogyakarta, Indonesia, 2005.

[9] F. Gefen, F. Karahanna, and D. W. Straub, "Inexperience and experience with online stores: The importance of TAM and trust," IEEE transaction on engineering management, vol. 50, pp. 307-321, 2003.

[10] C. L. Hsu, C. C. Lin, and Y. D. Lee, "Effect of commitment and trust towards micro-blogs on consumer behavioral intention: A relationship marketing perspective," International Journal of Electronic Business Management, vol. 8, no. 4, pp. 292-303, 2010.

[11] F. Garbarino and M. Johnson, "The different role of satisfaction, trust and commitment in customer relationships," Journal of marketing, vol. 63, no. 2, pp. $70-87,1999$.

[12] S. Y. Lam, V. Shankar, M. K. Erramilli, and B. Murthy, "Customer value, satisfaction, loyalty and switching cost: An illustration from a business to business service context," Journal of marketing Science, vol. 32, no. 3, pp. 293- 311, 2004.

[13] E. Mustafa, "Determinants of E-commerce customer satisfaction, trust and loyalty in Saudi ASrabia," Journal of Electronic Commerce Research, vol. 12, no.1, 2011.

[14] T. Heidt, T. V. Der, and P. Ponirin, Modelling the complexity of $e$ loyalty: The Role of e-Value, Trust, e-Satisfaction and $e$ Commitment, 2010

[15] J. Flint, C. Blocker, and P. Boutin, "Customer value anticipation, customer satisfaction, and loyalty: An empirical examination," Industrial Marketing Management, vol. 40, pp. 219-230, 2011.

[16] P. Kotler, Marketing Management, Prentice Hall, Inc, New York, 2010.

[17] S. Shoemaker and R. C. Lewis, "Customer loyalty: the future of hospitality marketing," International Journal of Hospitality Management, vol. 18, pp. 345-370, 1999.

[18] L. J. Reid and S. D. Reid, "Communicating tourism supplier services: building repeat visitor relationships," Communication and Channel Systems in Tourism Marketing, pp. 3-19, 1993.

[19] S. Ghane, M. Fatian, and M. R. Gholamian, "Full relationship among e-satisfaction, e-trust, e-service quality and e-loyalty: the case of Iran e-banking," Journal of Theoretical and Applied Information Technology, $15^{\text {th }}$ November, vol. 33, no. 1, 2011.

[20] R. L. Oliver, "Whence consumer loyalty?" Journal of Marketing, vol 63, no. 4, pp. 33-44, 1999.

[21] R. E. Anderson and S. S. Srinivasan, "satisfaction and e loyalty : a contingency framework," Psychology and Marketing, vol. 20, no. 2, pp. $123-138,2003$.

[22] Y. Liu, "The long term impact of loyalty programs on consumer purchase behavior and loyalty," Journal of marketing, vol. 17, no. 4 , pp. 19-35, 2007

[23] C. Flavian and M. Guinaliu, and R. Gurrea, "The role played by perceived usability, satisfaction, consumer trust on website loyalty," Information and Management, vol. 43, no. 1, pp. 1-14, 2006

[24] J. Tam, "Linking perceived service quality to relational outcomes in a chinese context," Journal of International marketing, vol. 24, pp. 7-23, 2012.

[25] A. Chaudhuri, M. B. Holbrook, "The chain of effects from brand trust and brand affect to brand performance: The role of brand loyalty," Journal of Marketing, vol. 65, no. 2, pp. 81-93, Doi:101.1509/jmkg.65.2.1.18255, 2001.

[26] P. Rauyenruan and K. E. Miller, "Relationship quality as a predictor of B2B customer loyalty," Journal of Business research, vol. 60, no. 1 , pp. $21-31,2007$

[27] M. D. Uncles, G. R. Dowling, and K. Hammond, "Customer loyalty and customer loyalty programs," Journal of Consumer Marketing, vol. 20, no. 4, pp. 294-316, 2003.

[28] F. B. Tan, L. Tung, Y. Xu, "a study of web designer criteria for effective business to cutomer (B2C) websites using the repertory grid technique," Journal of Ecommerce Research, vol. 10, no. 3, pp. 155-177, 2009.

[29] R. Frederick, M. G. Jr. Robert, and H. Christopher, "E-customer loyalty - applying the traditional rules of business for online success," European Business Journal, vol. 12, no. 4, pp. 173-179, 2000

[30] L. D. Pleessis, "Customer relationship management and its influence on customer loyalty at Liberty Life in South Africa," University of Johannesberg, 2010.
[31] R. T. Rust, A. J. Zahorik, "Customer Satisfaction, Customer Retention, and Market Share," Journal of Retailing, vol. 69, no. 2, pp. 193-215, 1993

[32] Bowen and Chen, "The relationship between Customer Loyalty and Customer Satisfaction," International Journal of Contemporary Hospitality Management, vol. 13, no. 5, pp. 213-217, 2001.

[33] T. H. Thurau and A. Klee, "The impact of customer satisfaction and relationship qualty on customer retention a critical reassessment and model development," Psychology \& Marketing, vol. 14, no. 8, pp. 737-765, 1997.

[34] A. Bryant and B. Colledge, "Trust in electronic commerce business relationships," Journal of Electronic Commerce Research, vol. 3, no. 2, pp. 3-39, 2002.

[35] M. A. Razzaque and T. G. Boon, "Effects of dependence and trust on channel satisfaction, commitment and cooperation," Journal of Business to Business marketing, vol. 10, no. 4, pp. 23-48, 2003.

[36] C. Terawatanavong, G. J. Whitwell, R. E. Widing, "Buyer satisfaction with relational exchange across the relationship lifecycle," European Journal of Marketing, vol. 41, no. 7-8, pp. 915938, 2007.

[37] D. Bejau, C. T. Ennew, and A. Palmer, "Trust, ethics and relationship satisfaction," International Journal of Bank Marketing, vol. 16 , no. 4, pp. 170-175, 1998.

[38] N. Rexha, R. P. John, and A. S. Shang, "The impact of the relation plan on ad option of electric banking," Journal of Services Marketing, vol. 17, no. 1, pp. 53-67, 2003.

[39] D. Ribbink, A. C. R. V. Riel, V. Liljander, and S. Streukens, "Comfort your online customer: Quality, trust and Loyalty on the internet," Managing Service Quality, vol. 14, no. 6, pp. 446-456, Journal of Services Marketing, vol. 17, no. 1, pp. 53-67, 2005

[40] Y. Bart, V. Shankar, F. Sultan, and G. L. Urban, "Are the drivers and role of online trust the same for all website and consumers? A large- scale exploratory empirical study," Journal of Marketing, vol. 69, pp. 133- 152, 2005.

[41] S. G. Krauter and Kaluschab, "Empirical reserch in on-line trust: A review andcritical assessment," Internaional Journal of Human Computer studies, vol. 58, no. 6, pp. 782- 812, 2003.

[42] D. Kim and I. Benbasat, "Trust related argument in internet stores: a frameworkfor evaluation," Journal of Electronic Commerce Research, vol. 4, no. 2, pp.49-64, 2003.

[43] K. Y. Lee, H. L. Huang, and Y. C. Hsu, "Trust, satisfaction and commitment on loyalty to international retail service brans," Asia Pacific Management review, vol. 12, no. 3, pp. 161 -169, 2007.

[44] P. A. Pavlou, "Consumer acceptance of electronic commerce integrating trust and risks with the technology acceptance model," International Journal of Electronic Commerce, vol. 7, no. 4, pp. 101- 134, 2003.

[45] J. Kim, D. Morris, and J. Swait, "Antecedents of true brand loyalty," Journal of Advertising, vol. 37, no. 2, pp. 99 - 117, 2008.

[46] S. P. Gounaris, "Customer retention: insights from business to business service," Journal of Business Research, vol. 58, no. 2, pp. $126-140$.

[47] R. M. Morgan and S. D. Hunt, "The commitment - trust theory of relationship marketing," Journal of marketing, vol. 58, no. 3, pp. 2038, 1994.

[48] H. Wang and H. Zhanming, "Online trust between inexperienced consumers and experienced consumers: an emperical stdy," Second international Conference on Future Information Technology and Management Engineering, pp. 167 -170, 2009.

[49] F. Wu and S. T. Cavusgil, "Organizational learning, commitment and joint value creation in intra-firm relationships," Journal of Business Research, vol. 59, pp. 81- 89, 2006.

[50] P. Luarn and H. H. Lin, "A customer loyalty model for e-service context," Journal of Electronic Commerce Research, vol. 4, no. 94, pp. $156-167,2003$.

[51] G. Fullerton, "The impact of brand commitment on loyalty to retail service brand, Canadian," Journal of Administrative Sciences, vol. 22, no. 2, pp. $97-110,2005$

[52] V. A, Zeithaml, L. L, Berry, and A. Parasuraman, "The behavioral consequences of service quality," Journal of Marketing, vol. 60, no. 2, pp. 41-46, 1996.

[53] Sugiono, Business Research Methodology, 2008.

[54] U. Sekaran and R. Bougie, Resarch Methods for Business: a skill building approach, Sixth edition. New York: John Wiley \& Sons, Ltd. Publication., 2010.

[55] B. G. Gomez, A. G. Arranz, and J. G. Cillan, "The role of loyalty programs in behavioral and affective royalty," Journal of Consumer Marketing, vol. 23, no. 7, pp. 387-396, 2006.

[56] F. A. Velenzuela and Y. A. V. Parraga, "Trust and Commitment as Mediataing Variables in the Relationship between satisfaction and 
Hotel guest Loyalty," Panoraman Socio economic, vol. 24, no. 32, pp. $18-23,2006$

[57] M. A. Jumaat and M. J. Yunus, "The relationship between customer commitment and satisfaction on the loyalty card program of department strores in Malaysia," Journal of problems and Perspective in Management, vol. 8 , issue 4, 2010.

[58] B. E. Delgad and A. J. L. Munuera, "Brand trust in the context of customer loyalty," European Journal of market researh, vol. 45, no. 1, pp. 35-53, 2001.

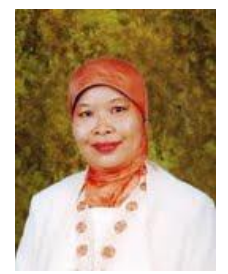

Sri Astuti Pratminingsih graduated in Business and Management at Sriwijaya University and received her Ph.D. of Business Management from the Philippine Christian University of Manila 2013.

She joined the Faculty of Business and Management of Widyatama University Bandung since 1996

Her research interests cover Marketing Management, and Human Resource Management in tourism and higher education.

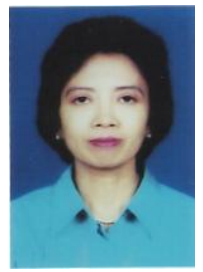

Christina Lypuringtyas Rudation is a lecturer of State Poly technique of Jakarta in Jakarta Indonesia. Her research interests are in Marketing Management and Human Resources development. She is now Ph.D. student in Indonesia University, Jakarta.

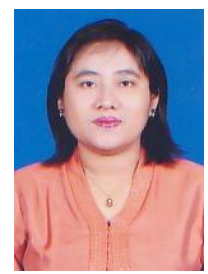

Tetty Rimenta is a lecturer of State Poly technique of Jakarta in Jakarta Indonesia. Her research interests are in Marketing Management and Human Resources development. She is Ph.D. candidate in Indonesia University, Jakarta. 